\title{
Clinical Test of Nanogold-Nanoseaweed Cosmetics For User Cosmetic Sociaty
}

\author{
Titik Taufikurohmah*, Tjandrakirana, Siti Tjahjani, I \\ Gusti Made Sanjaya, \\ Department of Chemistry, Faculty of Mathematic and \\ Natural Science \\ Universitas Negeri Surabaya \\ Surabaya, Indonesia \\ Correspondent Author: titiktaufikurohmah@unesa.ac.id
}

\author{
Hans Lumintang \\ Department of Medical \\ Universitas Widyamandala \\ Surabaya, Indonesia
}

\author{
Afaf Baktir, Achmad Syahrani \\ Departmen of Chemistry, Faculty of Science and \\ Technology, Universitas Airlangga \\ Surabaya, Indonesia \\ Achmad Syahrani \\ Departmen of Pharmacy, Faculty of Pharmacy \\ Universitas Airlangga \\ Surabaya, Indonesia \\ Adi Soeprijanto \\ Institut Teknologi Sepuluh Nopember \\ Faculty of Mechanical Engineering \\ Surabaya, Indonesia
}

\begin{abstract}
The true using of cosmetics will give so many good effects such as healthy, elastic and younger face, otherwise bad using of cosmetics can cause many problems such as Acne, spot, oily skin and dry skin. This clinical research using nanogold and nanoseaweed was aimed as a solution for negative effect of cosmetics. This research service society from Surabaya and other area involving 254 volunteers where 48 volunteers among them full field 4 weeks trial. The data volunteers taken were face-scant data and medical report. The medical report data of 48 volunteers were: $29,2 \%$ with acne problems, $25 \%$ oily problems, $29,2 \%$ spot problems and $16,6 \%$ in normal condition with different cosmetics utilization story. The face scant data of volunteers show that recovery progress occurred step by step in the range time 1-4 weeks with different condition. The result of this Nanogold and nanoseaweed research in the cosmetics formulation can reduce the cosmetic problems and can give better skin healthy. The impact of this research will making the society not worry to use Nanogold-Nanoseaweed cosmetics so that the fabrication process of these cosmetics can be accelerated.
\end{abstract}

Keywords-: cosmetics, nanogold-nanoseaweed, acne, spot, clinical test

\section{INTRODUCTION}

Human has used Cosmetics for a long time ago. Cosmetics used to get a beauty, interesting performance and to hide bed physical. The function of cosmetics change allow changes of society. The rational thinking that healthy was important than beautifully. Modern cosmetics just not used to support beautifully, so that it was care healthy [1]. The skin with healthy care and positive thinking in everything create beautifully building of human charming face. Than the cosmetics that true health care was be important to be there. The cosmetics with true formulation was needed. It is the modern cosmetics that must be production for modern society [2]. The dangerous material content don't be used in cosmetics formulation. It was the warning that must be done in cosmetics production in the world.

Although so many good information and good formulation product in cosmetics, there are steel cosmetics user get mercury exposure. The aim of good cosmetics was not yet helpful all person in society. Many people still use dangerous material in their cosmetics. Part of them was known that and others was not known [1]. The dangerous material for example mercury in cosmetics, support many trouble and up normal metabolism in the body. In the long time using mercury caused skin destroy that following many destroy in the body [3]. The common dangerous content in whitening cosmetics was mercury that form binding with thiol in enzyme and hormone. This binding that form caused enzyme and hormone have not activity [4]. The drastically effect of mercury whitening cream was very interesting, than cause cosmetic user forget the dangerous that following [5]. Stopping of using mercury whitening cream cause skin hyperpigmentation that show many spots in face skin and rough skin be occurred.

The clinical research of Nanogold-nanoseaweed to reduce effect of mercury in cosmetics and reduce impact in society have been done. Nanogold can recovery tissue destroying because nanogold accelerate cell proliferation and collagen quantity. This recovery begin form binding gold with thiol group in enzyme molecule. This binding change mercury position in thiol and then prevent of forming free radicals [6]. The clinical research done in Medical Centre of Universitas Negeri Surabaya (Unesa) that present volunteer from Surabaya 
and surrounding areas. Nanogold-nanoseaweed cosmetics was cosmetics that content active material gold nanomaterial and seaweed nanomaterial. Nanogold give chatalytical effect to form tissue including tissue of skin. Nanoseaweed was essential nutrition to form tissue skin and many others [7]. These research activities are part of the national strategic Flagship Research PUSN fiscal year 2017 which carried out work in research institutions and Community service LPPM under Unesa.

Nanogold resulted from synthesis with the starting materials in the form metals salts of pure gold that obtained from PT Aneka Tambang or better known as Antam Gold, a slab being sold in jewellery stores although not including the type of jewellery. Gold has been used by our ancestors as pegs gold which is believed to give efficacy to maintain the beauty and health of the body. Scientific research about the benefits of gold in the form of metal is included in living tissue known as implants turned out to support a truth known gold pegs before [6]. Gold metal in a liquid body cells will be liberate in small units which consists of a collection of atoms or clusters with a diameter 1-100 nm, better known as Gold nanomaterial or nanogold [8].

Nanogold has been invitro tested at free radicals and it was a powerful antioxidant than vitamin $\mathrm{E}$ or Vitamin $\mathrm{C}$ [9]. Nanogold in cosmetic formula will increase the proliferation of fibroblasts cells so that the regeneration of the skin occur regularly and skin look young and clean [10]. Nanogold has also been proven to increase the secretion of collagen by fibroblasts cells so that the elasticity of skin stays care although the age grow older [11][5]. On the basis of the above, the development of cosmetic formula nanogold is very promising great hope for the restoration of skin damage due to cosmetics containing hazardous materials. Contaminated skin harmful substances will be replaced gradually by a new skin that healthier.

Seaweed is a natural ingredient containing nutritionessential nutrients necessary to compose in biochemistry of skin cells, collagen and other related connecting tissue [7]. Seaweed contains active compounds that moisturizes the skin and accelerate the process of the biosynthesis of collagen so it can be used as material to rejuvenate the skin or antiaging materials along with other constituent materials basic [12]. The patent about the usefulness of seaweed that others mention that protein content on algae and seaweed is a nutrient essential for drawing up the skin and hair so that the protein extract of algae and seaweed can be used in cosmetic formulas skin, hair care formulas and also compounds essential skin cleaning products [13][14]. Seaweed material that was fabricated in advance as the nanomaterials used in cosmetic preparations facial cream formula as a material for the nutrition of the skin.

Nanogold and nanoseaweed are all used simultaneously in cosmetic formulas that distributed on volunteers in the form of day cream and night cream. Volunteers have agreements with researchers to continuous visit to the clinic to be examined medically skin face and also taken photos of their faces for four consecutive weeks. Medical record data for 4 weeks consecutive face photos and data for 4-week data for this research. Quantitative descriptive analysis will be made clear with a simple chart to show the progression of skin health volunteers step by step during use of the nanogoldnanoseaweed face cream.

Formulation of research problem are: 1. How to acne, freckles, oily and dry skin which is a volunteer complaint after using cosmetics nanogold-nanoseaweed. Formulation problem no. 2. If the data record medical volunteers supported image data the development of facial skin health in General.

\section{MATERIAL AND METHOD}

The material used of clinic trials face cream containing nanogold $20 \mathrm{ppm}$ and 5\% nanoseaweed made with reference to patents and patent P00201100426 new registered in 2017 i.e. P00201705278: P00201705279: P00201705280 and P00201705281. Cream that used in this clinic test are day cream and night cream for all skin types.

The Method that used in these clinical research: Manage to volunteer user community with the subject of cosmetic in Surabaya and surrounding areas. Age restriction that is 15 years of age [4] and their volunteers have signed an agreement setting up the test subjects as cosmetic of nanogold (inform consent). The study begins with an adequate explanation of the related actions to be given on a volunteer that volunteers would be vetted health skin face for 4 times in a row which is done every Saturday or Sunday. Volunteers are required to test cream slathered in the morning and also at night with Nanogold cream test are distributed. Volunteers signed the agreement along with the investigators and witnesses. Research data obtained medical inspection results data are a dermatologist and facial photos of volunteers results data that is taken or photographed by the research team 4 consecutive weeks. Methods and research implementation plan has been authorized by the Ethyc Commission of community health Faculty Airlangga University Surabaya by published certificate of Ethical Clearance.

\section{RESUlT AND DiSCUSSION}

Clinical test results obtained two medical record Data i.e. data recorded by skin specialist Dr. Hans Lumintang, SP. KK $(\mathrm{K})$. The second data in the form of a volunteer face photo data is also presented in the Commission report as a form of accountability Ethyc researchers against the condition of volunteers for clinical and research and the volunteer medical record supporting data.

\section{Medical Volunteer Data for 4 weeks}

Clinical trials for 4 weeks, has served as many as 254 volunteers. The data of these regularly for 4 consecutive weeks as many as 48 people. Thus it was decided to undertake an analysis of the 48 volunteers. Next of 48 volunteers are divided into 4 categories of complaint, namely: a. the complaint the skin breakouts, b. complaints of dry skin and stained black, c. Complaint d. oily skin and normal skin. For each category of complaints try analyzed more deeply linked than the original 
face cream that has been used in the last year. Obtained grouping category hasn't used creamy facial, product fabrication and cosmetic from the clinic.

\section{1a. Medical Data volunteers for Complaints of acne}

TABLE I. MEdicAl DATA CATEGORY SKIN WITH ACNE

\begin{tabular}{|l|l|l|l|l|}
\hline Identity & \multicolumn{4}{|c|}{ Weeks } \\
\hline & W-1 & W-2 & W-3 & W-4 \\
\hline Never Used cosmetics volunteer \\
\hline 201 & 1 & 2 & 3 & 4 \\
\cline { 2 - 5 } 132 & 1 & 2 & 3 & 4 \\
45 & 1 & 2 & 3 & 4 \\
Factory cosmetic & & & & \\
user & & & & \\
200 & 1 & 2 & 3 & 4 \\
192 & 1 & 1 & 2 & 3 \\
190 & 1 & 1 & 2 & 4 \\
134 & 1 & 2 & 3 & 4 \\
104 & 1 & 2 & 3 & 4 \\
17 & 1 & 2 & 3 & 4 \\
Clinical cos user & & & & \\
138 & 1 & 2 & 1 & 4 \\
181 & 1 & 2 & 3 & 4 \\
173 & 1 & 1 & 2 & 2 \\
89 & 1 & 2 & 3 & 4 \\
51 & 1 & 2 & 3 & 4 \\
\cline { 2 - 5 } & & & & \\
\hline
\end{tabular}

Description:

1. the condition of Breakouts acne

2. the condition of Acne was reduced

3 . most of the acne dries and recovers

4. reduced acne spot to disappear.

Based on the data in Table I, volunteers who have never used cosmetics is experiencing a very good development during the 4th week of acne has been recovered and even freckles acne scars also disappeared and the skin back to normal no breakouts. For volunteer users of cosmetics manufacturers there is 1 of the 6 people who have yet to match expectations i.e. there are still stains the acne scars. Volunteer users of beige clinic 2 of 5 orang experienced a longer recovery process whereby to Sunday ke4 one person still breakouts and one new acne dries up.

\section{1b. Volunteer Medical Data for complaints of Spot}

From Table II, data For volunteers who have never used cosmetics, pure black stains due to sunburn experienced a rapid recovery in which progress during the 4 weeks of wearing the stain was gone, the skin moist, fresh and toned. As for the volunteers who use the products manufactured in General has experienced a gradual recovery, but there is one of the 10 volunteers experienced a delay in recovery where the 2 nd week of the condition have not undergone repair and 4th week of the black stains are still visible Although the skin is already moist and firm. For volunteer users of beige clinic as much as 4 people, two of them succeed where in week 4 skin smooth, toned and black stains disappear. But the two volunteers have not managed where after thinning the stain in the first week and then appear black stain on the 2nd Sunday of even until the 4th week of black stains have not been reduced despite the skin already moist and smooth.

TABle 2. Medical Data of VolunteER With SPOT

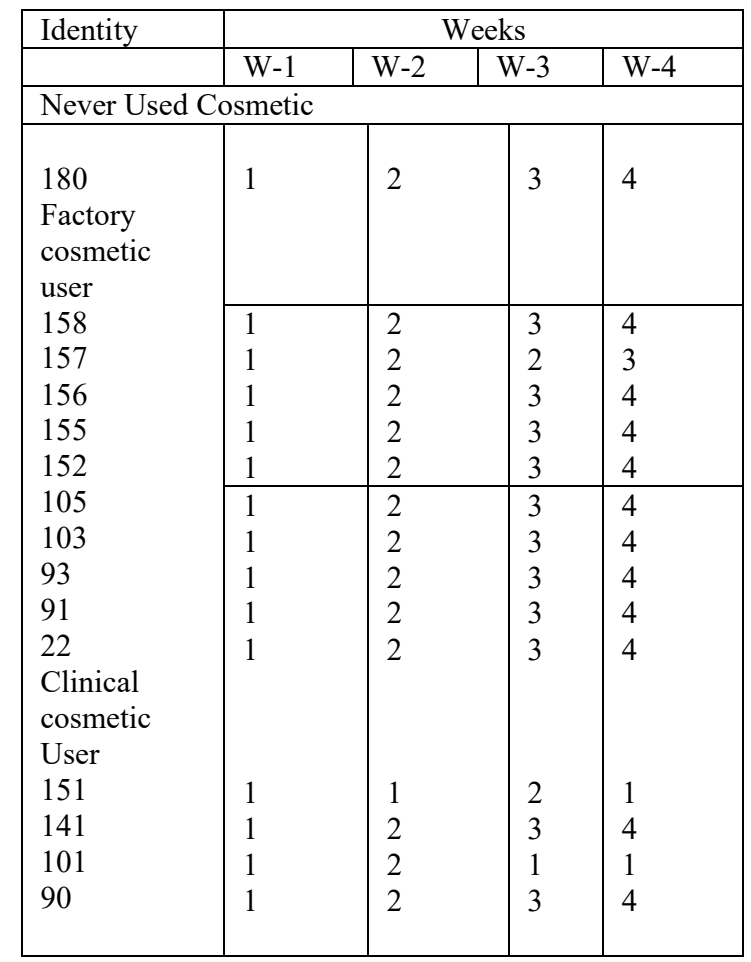

Description:

1. Dry skin, stained and skin tone uneven.

2. The skin early moist and spot reduced.

3. Fresh and moist, Skin spot was reduced.

4. Skin smooth, toned, the spot was gone.

\section{1c. Medical Data of volunteer with oily skin}

TABLE 3. MEDICAL DATA OF VOLUNTEER WITH OILY SKIN

\begin{tabular}{|c|c|c|c|c|}
\hline Identity & \multicolumn{4}{|c|}{ Weeks } \\
\hline & W-1 & $\mathrm{W}-2$ & W-3 & W-4 \\
\hline \multicolumn{5}{|c|}{ Never Used Cosmetic } \\
\hline 179 & 1 & 2 & 3 & 4 \\
\hline $\begin{array}{l}\text { Factory } \\
\text { cosmetic } \\
\text { user }\end{array}$ & & & & \\
\hline 178 & 1 & 2 & 3 & 4 \\
\hline 177 & 1 & 2 & 3 & 4 \\
\hline 117 & 1 & 2 & 3 & 4 \\
\hline 116 & 1 & 2 & 3 & 4 \\
\hline 115 & 1 & 2 & 3 & 4 \\
\hline 110 & 1 & 2 & 3 & 4 \\
\hline 108 & 1 & 2 & 3 & 4 \\
\hline 88 & 1 & 2 & 3 & 4 \\
\hline 67 & 1 & 2 & 3 & 4 \\
\hline 37 & 1 & 2 & 3 & 4 \\
\hline $\begin{array}{l}\text { Clinical } \\
\text { cosmetic }\end{array}$ & & & & \\
\hline
\end{tabular}




\begin{tabular}{|l|l|l|l|l|}
\hline Identity & \multicolumn{4}{|c|}{ Weeks } \\
\hline & W-1 & W-2 & W-3 & W-4 \\
\hline $\begin{array}{l}\text { User } \\
19\end{array}$ & 1 & 2 & 1 & 1 \\
\cline { 2 - 5 } & & & & \\
\hline
\end{tabular}

Description:

1. Oily skin, large pores, dull.

2. Oil decreases, pores decrease in size.

3. Fresh skin, pores shrink, tight.

4. Smooth skin, shrinking pores, fresh and tight.

From Table III, data shows that for volunteers who have never used cosmetics, oily skin problems are resolved well after 4 weeks of routine using test cream. Likewise for cosmetic manufacturing volunteers, oily skin problems were resolved for 4 weeks using test cream. For volunteers who use beige from the clinic, they experience different conditions, after 4 weeks the skin remains oily even though it was reduced at 2 weeks, so it is recommended to use excess oil-absorbing rice milk soap.

\section{1.d. Normal Skin Volunteer Medical Data}

TABLE 4. Medical Data CATEgory Normal SkIN

\begin{tabular}{|l|l|l|l|l|}
\hline Identity & \multicolumn{4}{|c|}{ Weeks } \\
\hline & W-1 & W-2 & W-3 & W-4 \\
\hline Never Used Cosmetics & 2 & 3 & 4 \\
\hline \multirow{4}{*}{44} & 1 & & & \\
Factory & & & & \\
cosmetic & & & & \\
User & & & & \\
71 & 1 & 2 & 3 & 4 \\
70 & 1 & 2 & 3 & 4 \\
43 & 1 & 2 & 3 & 4 \\
26 & 1 & 2 & 3 & 4 \\
23 & 1 & 2 & 3 & 4 \\
Clinical & & & & \\
Cosmetic & & & & \\
User & & & & \\
& & & & \\
107 & 1 & 2 & 3 & 4 \\
80 & & & & \\
& & & & \\
\end{tabular}

\section{Description:}

1. Normal skin

2. Normal skin, fresher and smoother

3. Normal skin, fresher, smoother bright and toned

4. Normal skin, fresh, bright, tight and radiant on tip of the cheeks and nose.

From Table 4. It can be seen that the data shows that for normal skin conditions without complaints all volunteers experience gradual and real skin health development. Nanogold nanomaterial seaweed gives skin changes to a healthy condition characterized by skin that looks fresh, bright, moist, tight, smooth and radiant. Thus the volunteers and the wider community do not need to doubt these test cosmetics which will soon be mass produced by PT. Indonesian Nutrition as a manifestation of the cooperation between Surabaya State University and the cosmetic company.

\section{Data of volunteer face photos for 4 weeks (sampling 6 of 48 volunteers)}

Face photo data displayed only 6 people for 4 or 4 weeks of shooting as representative of real conditions representing volunteer data during the use of this nanogold nanomaterial seaweed cream. The medical record shown is for all volunteers.

From the photos of face photos during 4 shots or 4 weeks clinical trials showed that volunteers experienced improved skin health conditions for acne, black, oily and normal skin. No one has a negative condition or decreased skin health which is characterized by increasingly severe damage. In general, conditions improved, although for some volunteers, they did not meet expectations.

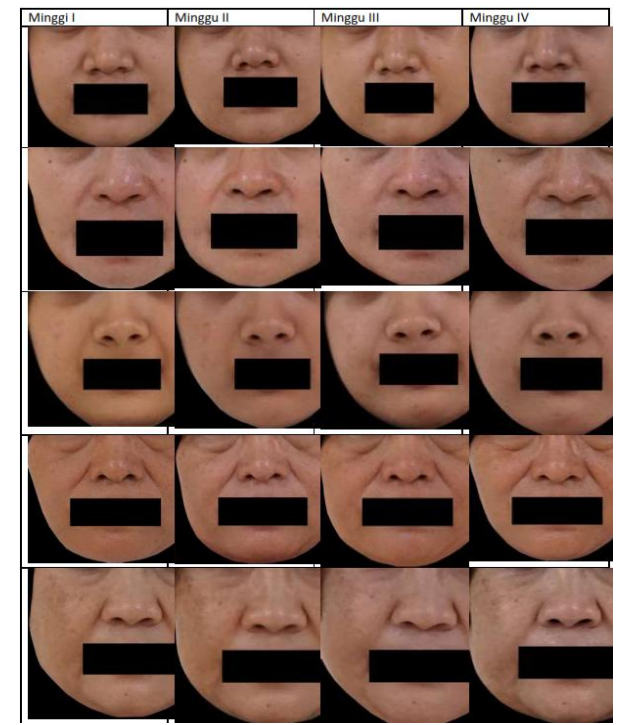

Fig. 1. Volunteer Face Scan For 4 weeks

\section{CONCLUSION}

From the results of clinical research that has been done can be concluded as follows:

1. There was an improvement in the skin health conditions of the volunteers with complaints of black stains and a reduction in stains until the recovery conditions of black stains faded and disappeared. As for acne conditions, there is also a decrease in acne to acne scars which are also corrected or lost. For oily complaints there is also a decrease towards normal skin. As for normal skin conditions, there is an increase in skin brightness, smoothness, freshness and even glowing skin conditions that show excellent skin health quality.

2. Medical record data along with medical reviews are strongly supported by the real condition of volunteers' skin health which is displayed in the form of photos of the faces of the volunteers. 


\section{ACKNOWLEDGMENT}

Acknowledgments delivered by the Research Team to:

1. Kemristek-Dikti through PUSN's National Strategic Leading Research program 2017 fiscal year as the largest funder in this research activity.

2. Surabaya State University which has provided in-kind donations through LPPM, Unesa Medical Centre and Chemistry Departments which has provided facilities both for Nanomaterial Synthesis, product development and cosmetic tests produced.

3. PT. Gizi Indonesian which has contributed both in-kind and in-cash to product collaboration development, POMMUI registration and facilities and infrastructure.

\section{REFERENCES}

[1] T. Kim, H.J. Kim, S.K. Cho, W.Y. Kang, H. Baek, H.Y. Jeon, B. Kim and D. Kim, "Nelumbo nucifera extracts as whitening and anti-wrinkle cosmetic agent". Korean J. Chem. Eng., vol. 28, pp. 424-427, 2011.

[2] T. Taufikurohmah, I.G.M. Sanjaya, A. Syahrani, "Nanogold synthesis using matrix mono glyceryl stearate as antiaging compounds in modern". Cosmetics. J. Mater. Sci. Eng., A 1, pp. 857-864, 2011.

[3] J. Bourdineaud, M. Laclau, R. Maury-brachet and P. Gonzalez, "Effects of methylmercury contained in a diet mimicking the Wayana Amerindians contamination through fish consumption: Mercury accumulation, metallothionein induction, gene expression variations, and role of the chemokine CCL2, pp. 7710-7738. doi:10.3390/ijms130677102012, 2007.

[4] A. Karnani, "Doing well by doing good-case study:'Fair \& lovely'whitening cream. Strateg. Manag. J. vol. 28, pp. 1351-1357, 2007.

[5] T. Taufikurohmah, A. Soegianto, I.G.M., Sanjaya, A. Baktir and A. Syahrani, "Mercury exposure effects to skin tissue of mus muscullus at fibroblasts cell proliferation and collagen quantity". Res. J. Pharm. Biol. Chem. Sci., vol. 4., 2013.

[6] F.K. Alanazi, A.A. Radwan, I.A. Alsarra, "Biopharmaceutical applications of nanogold". Saudi Pharm. J., 2010.

[7] P. Kuppusamy, M.M. Yusoff, G.P. Maniam and N. Govindan, "Biosynthesis of metallic nanoparticles using plant derivatives and their new avenues in pharmacological applications ??? An updated report", Saudi Pharm. J. vol. 24, pp. 473-484. doi:10.1016/j.jsps.2014.11.013, 2016.

[8] A. Casini, M.C. Diawara, R. Scopelliti, S.M.Gr.M. Zakeeruddin and P.J. Dyson, "Synthesis, characterisation and biological properties of gold (III) compounds with modified bipyridine and bipyridylamine ligands $\dagger$, 2010, pp. 2239-2245.

[9] T. Taufikurohmah, I.G.M. Sanjaya, A. Baktir and A. Syahrani, Activity Test of Nanogold for Reduction of Free Radicals, a Pre-Assessment Utilization Nanogold in Pharmaceutical as Medicines and Cosmetics 2, 2012, pp. 611-617.

[10] T. Taufikurohmah, D. Winarni, A. Baktir, I.G.M. "Sanjaya and A. Syahrani, Histology Study: Pre-Clinic Test of Nanogold in Mus Musculus Skin", Fibroblast Proliferation and Collagen Biosynthesis, vol. 3, pp. 55-61, 2013.

[11] C.Y. Tsai, A.L. Shiau, S.Y. Chen, Y.H. Chen, P.C. Cheng, M.Y. Chang, D.H. Chen, C.H. Chou, C.R. Wang and C.L. Wu, "Amelioration of collagen-induced arthritis in rats by Nanogold". Arthritis Rheum., vol. 56, pp. 544-554, 2007.

[12] S. Al-Edresi, S. Baie, "Formulation and stability of whitening VCO-inwater nano-cream". Int. J. Pharm.. vol. 373, pp. 174-178, 2009.

[13] T. Rahman, M.A. Fadhlulloh, A.B.D. Nandiyanto, J. Setiabudhi and J. Barat, Review: Sintesis Titanium Dioksida Nanopartikel 1. Program Studi Kimia, Jurusan Pendidikan Kimia, Fakultas Pendidikan Matematika dan Ilmu Pengetahuan Alam, Universitas Pendidikan Indonesia 5, 2014, pp. 15-29.
[14] K.I.M.J. Keun, L.I.M.Y. Hee, K.I.M.M.I. Jin, KR20100056422A Cosmetic compositions for whitening skin comprising extracts from mulberry root hydrolyzed by enzymes. Pat KR., 2010. 